\title{
Multiscale Approach to Dairy Products Design
}

\author{
Martha L. Díaz-Bustamante ${ }^{1}$, Miguel Fernández-Niño ${ }^{2}$, Luis H. Reyes ${ }^{1 *}$ and \\ Oscar Alberto Alvarez Solano ${ }^{1 *}$ \\ ${ }^{1}$ Department of Chemical and Food Engineering, University of Los Andes, Bogotá, Colombia, ${ }^{2}$ Department of Bioorganic \\ Chemistry, Leibniz Institute of Plant Biochemistry, Halle, Germany
}

Dairy products are among the most popular nutritious foods in the world. Understanding the relationship between the composition, process, and structural properties at different scales (molecular, microscopic, and macroscopic) is fundamental to designing dairy products. This review highlights the need to analyze this relationship from different scales as an essential step during product design through a multiscale approach.

Keywords: multiscale, dairy, product design, molecular properties, microscopic properties, macroscopic properties

\section{OPEN ACCESS}

Edited by:

Xiaoguang (Margaret) Liu,

University of Alabama at Birmingham,

Birmingham, United States

Reviewed by:

Suwattana Pruksasri, Silpakorn University, Nakhon Pathom,

Thailand

Jiajia Song,

Southwest University, Chongqing,

China

${ }^{*}$ Correspondence: Luis H. Reyes Ih.reyes@uniandes.edu.co Oscar Alberto Alvarez Solano oalvarez@uniandes.edu.co

Specialty section:

This article was submitted to Biochemical Engineering,

a section of the journal

Frontiers in Chemical Engineering

Received: 07 December 2021 Accepted: 02 February 2022

Published: 24 February 2022

Citation:

Díaz-Bustamante ML,

Fernández-Niño M, Reyes $L H$ and Alvarez Solano OA (2022) Multiscale Approach to Dairy Products Design.

Front. Chem. Eng. 4:830314.

doi: 10.3389/fceng.2022.830314

\section{INTRODUCTION}

Dairy products are foods derived from milk that provide nutrients such as proteins, fatty acids, vitamins, and minerals, essentials for function, growth, and the human body's development (Khan et al., 2019; Tunick and Van Hekken 2014). The high nutritional consumption of dairy products worldwide has resulted in the development of novel techno-functional products in the dairy industry (Farhana et al., 2018). Unfortunately, the design of foods using novel ingredients and technologies has been shown to affect the sensory profile and food structure, which consumers perceive as texturally less attractive (Aguilera 2006; Mousavi et al., 2019).

The structure of dairy products consists mainly of milk proteins, fat, water, lactose, and salts. After processing, these molecular components experience changes that define dairy food's typical appearance, taste, aroma, and texture (Spyropoulos et al., 2019). Generally, the food industry monitors its products by controlling their properties during the production and formulation stages. Consequently, the molecular interactions between the components, ingredients, and additives that are part of the formation and structuring are usually not considered during the food production process. Therefore, understanding the relationship between dairy products and their structure is essential to designing novel products that can be more attractive to consumers (Dickinson 2014; Heertje 2014).

Food structure can be considered the link between molecular, microscopic, and macroscopic properties. At the molecular scale, the complex interactions determine the subsequent microscopic properties. At the microscopic scale, it is possible to decide on the textural and rheological properties at the macroscopic scale (Crilly et al., 2008). Understanding the relationship between composition and formulation, the manufacturing process, and the properties of food through these scales is therefore essential for designing a product with specific sensory, stability, shape, and nutritional properties (Ho et al., 2013).

A way of understanding, predicting, and studying the relationships between scales during product design is using a multiscale approach (Crilly et al., 2008; Ho et al., 2013; Huc et al., 2016). The multiscale approach creates a geometric model of the food structure and correlates the scales. This approach allows the analysis and study of behaviors associated with food development's process, product, and properties (Ho et al., 2013). It allows taking advantage of molecular interaction on microscopic and macroscopic properties to design a food structurally. 
Consequently, the multiscale approach can be considered an essential tool for designing new dairy products.

Recent research focuses on understanding food structure without jointly considering texture, rheology, microstructure, and the behavior of molecular components involved in food structure formation. This review emphasizes the relevance of considering the interactions between the molecular, micro, and macro scales and their relationship with the steps of the dairy product development process. It provides a comprehensive overview of the factors that affect the structure of dairy products and their relationship with other food properties. This review's scope considers the following dairy products: yogurt, cheese, ice cream, and butter.

\section{DAIRY PRODUCT DESIGN FROM A MULTI-SCALE PERSPECTIVE}

Dairy products are foods mainly associated with the human body's development and functionality (Pereira 2014). These products are either high milk protein (e.g., yogurt and cheese) or high-fat content (e.g., butter and ice cream). Yogurt is produced by the fermentation of milk with lactic acid bacteria, while cheese is made by adding rennet enzyme (Chymosin and pepsin) to the milk (Guinee 2016). When milk proteins (casein) coagulate in yogurt and cheese, they form three-dimensional protein networks that trap fat (El-Bakry and Sheehan 2014; Giha et al., 2021; Guinee 2016). On the other hand, butter is a milk fatbased product generally characterized as a water-in-oil emulsion. (Panchal et al., 2021; Truong et al., 2016). Ice cream is a complex multiphase structure containing protein, water, crystallized fat, air, minerals, additives, and sweeteners (Kaleda et al., 2018).

The structure of dairy products can be analyzed through properties at the molecular, microscopic, and macroscopic scales (Figure 1). Mixtures of molecular components such as proteins, fat, water, carbohydrates, salts, and the interactions between water-casein, casein-casein, and casein-minerals define the dairy product structure (Heertje 2014). While these molecular elements can be studied considering $\mathrm{pH}$ changes, ionic strength, or hydrophobic interaction (Lucey and Horne 2018), the microscopic scale shows the spatial distribution and particle size/shape of these components, and the macroscopic scale reflects the perception of them in textural and rheology properties (Figure 1).

The formation of the structure of a food is equally dependent on processing (Dickinson 2014). The manufacturing process, like heating, gelation, fermentation, and ripening, among others (Smith et al., 2017), significantly affects the structure of molecular components, which in turn generates changes in the dairy food structure (Joardder et al., 2015). Therefore, ingredient

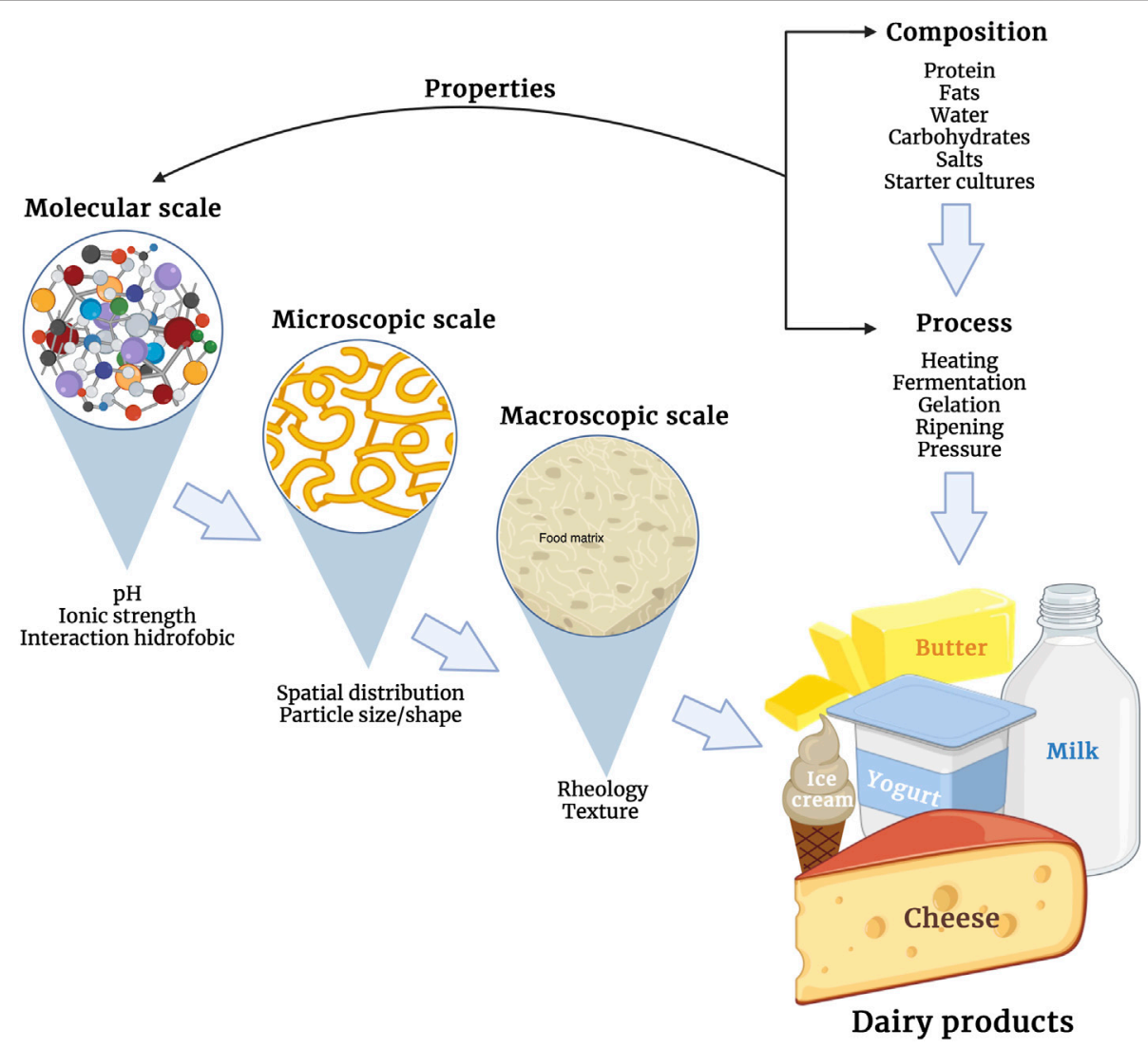

FIGURE 1 | Schematic representation of the relationship between properties scales of dairy products. 
composition and processing conditions are mechanistically related to product properties (Aguilera 2006; Dickinson 2014) (Figure 1).

Few studies about dairy products have integrated the relationship between product-process-properties from the multi-scale perspective. For example, Huc et al. (2016) investigated different yogurts' physical properties, analyzing the correlation between fat and protein content, size particle, and rheology properties under temperature conditions, considering the tribology as element additional. As a result, the authors showed that it was possible to obtain information relevant to yogurts' formulation to improve eating. As another example, Diaz-Bustamante et al. (2020) studied the substitution and reduction of $\mathrm{NaCl}$ in Costeño-type artisan cheese applying multiscale modeling. This study showed that it was possible to obtain cheeses with physicochemical composition and textural properties similarities of a cheese control, making variations in the $\mathrm{NaCl}$ addition and the manufacturing process. The previous examples show that the dairy products design's main challenge is understanding the association between structural scales, composition, and processing, determining the final structure. Therefore, one way to approach this is to visualize dairy products as foods with a multiscale structure where fundamental molecular, microscopic, and macroscopic properties (contributing to structure and sensory characteristics) can be addressed.

\subsection{Dairy Products on a Molecular Scale}

Food structure is primarily based on their molecular composition, so small changes at this level can induce dramatic structural changes (Barroso da Silva et al., 2020; Heertje 2014). Caseins, fat, lactose, and salts define the molecular composition of a dairy product. Milk is a colloidal dispersion of these molecular components (Foegeding 2015). These components play a significant role in dairy products' stability and nutritional value and contribute to their micro and macroscopic properties.

Caseins are the main molecular components defining the structure of dairy products (Spyropoulos et al., 2019). Thus, understanding casein's network is crucial for improving its processing stability. Caseins are phosphorylated and hydrophobic proteins that can self-assemble and interact strongly with multivalent cations involving molecular properties like ionic strength, hydrophobic interaction, and $\mathrm{pH}$ (Lamichhane et al., 2018; Spyropoulos et al., 2019). These proteins are classified into four groups (i.e., $\alpha s_{1}-, \alpha s_{2}-, \beta-$, and $\kappa$-caseins) representing $80 \%$ of total milk protein. During the cheese and yogurt manufacturing process, $\kappa$-casein, responsible for the electrostatic and steric stabilization of casein micelles, is destabilized by rennet enzymes leading to fermentation or gelation. As a result, it forms a three-dimensional network of protein aggregates, whose stability depends on temperature and mechanical action (Loveday et al., 2013; Moussier et al., 2018). These processes change the residual charges on the casein molecules and the electrostatic and hydrophobic interaction strength between them (Spyropoulos et al., 2019).

Dairy from cows may be subjected to thermal treatments to reduce the growth of pathogenic bacteria (Wiking et al., 2021).
However, heating milk to over $70^{\circ} \mathrm{C}$ leads to the denaturation of whey proteins, resulting in protein complexes formed from disulfide bonds with $\kappa$-casein, and this, in turn, affects manufacturing processes such as cheese coagulation (Asaduzzaman et al., 2021; Giroux et al., 2020; Lucey et al., 2021). It is worth noting that not only does heat affect the structure, conformation, and properties of whey proteins, but also these proteins are affected by $\mathrm{pH}$ and ionic strength (Anema 2019; Ong et al., 2020). Although milk is treated with heat in the manufacture of cultured dairy products to increase viscosity and improve texture (Lucey et al., 2021; Zhao et al., 2016), this process also induces several molecular changes in the milk fat globule affecting its functionality (Wiking et al., 2021).

The $\mathrm{pH}$ is another parameter that influences the fermentation and gelation of caseins and modifies their net charge (Ong et al., 2012). In the case of milk, the $\mathrm{pH}$ value will vary depending on the effect of the starter cultures or acidulant added (Ong et al., 2012; Spyropoulos et al., 2019). For instance, during fermentation of yogurt, lactic acid bacteria reduce the milk $\mathrm{pH}$ to the isoelectric point of casein, which is $\mathrm{pH} 4.6$, leading to micelle aggregation because of the reduction of the net negative charge of proteins (Zhao et al., 2016). In cheese, milk pH affects the way casein micelles aggregate. At lower $\mathrm{pH}$, there is an increase in the number of $\mathrm{Ca}^{+2}$ ions in solution, which reduces the surface potential of the $\kappa$-casein and causes dissociation between casein micelles (Ong et al., 2012). On the other hand, pH can be considered a molecular property and a process variable that can increase yield and alter texture in Cheddar cheese (Ong et al., 2012).

Interactions of caseins with other molecular compounds, such as fat globules, water, and minerals, also play an essential role in defining the structure of dairy products. For instance, the fat globule size can alter the casein strand formation during rennetinduced coagulation of milk (Lamichhane et al., 2018). On the other hand, the function of fat globules in ice cream is different; they have a specific role in stabilizing the bubbles and are responsible for the product's creamy texture (Bhopatkar et al., 2012). The interactions of water-casein through hydrogen bonding can increase the moisture content and be measured as the water capacity of a protein or the total amount of water that can be absorbed per protein weight (Aryee et al., 2018; Lamichhane et al., 2018). The addition of calcium chloride influences the stabilization of casein micelles, and it is commonly used to improve clot formation and increase cheese yield (Soodam et al., 2015). The addition or reduction of salts such as $\mathrm{NaCl}$ or $\mathrm{KCl}$ can also affect the stability of casein, which influences textural and rheological properties in products such as Costeño-type artisan cheese (Diaz-Bustamante et al., 2020).

All the above-mentioned molecular components and their structure differ among dairy products after processing; as a result, these various structures also impact their micro and macrostructure properties (Aguilera 2006). Therefore, this correlation can be analyzed by scanning electron microstructure (SEM), rheology behavior, and texture (Huc et al., 2016; Loveday et al., 2013; Verboven et al., 2018). Another experimental method can be zeta potential, which has been assessed under different processing conditions and milk 
TABLE 1 | Current strategies used in the development of new dairy products.

\begin{tabular}{|c|c|c|c|c|c|c|c|}
\hline \multirow[t]{2}{*}{ Product } & \multirow[t]{2}{*}{ Composition } & \multirow[t]{2}{*}{ Process stage } & \multicolumn{3}{|c|}{ Properties } & \multirow[t]{2}{*}{ Strategy } & \multirow[t]{2}{*}{ Authors } \\
\hline & & & Molecular & Microscopic & Macroscopic & & \\
\hline \multirow[t]{2}{*}{ Yogurt } & - & - & $\mathrm{pH}$ & - & $\begin{array}{l}\text { Rheology (storage modulus, G') } \\
\text { and sensory properties. }\end{array}$ & $\begin{array}{l}\text { Product }+ \\
\text { properties }\end{array}$ & $\begin{array}{l}\text { Pachekrepapol } \\
\text { et al. (2021) }\end{array}$ \\
\hline & - & - & $\begin{array}{l}\mathrm{pH} \text { and } \\
\text { titratable } \\
\text { acidity }\end{array}$ & $\begin{array}{l}\text { Scanning } \\
\text { electron } \\
\text { microscopy }\end{array}$ & $\begin{array}{l}\text { Texture (firmness and apparent } \\
\text { viscosity) }\end{array}$ & $\begin{array}{l}\text { Product + } \\
\text { properties }\end{array}$ & $\begin{array}{l}\text { Vianna et al. } \\
(2017)\end{array}$ \\
\hline \multirow[t]{2}{*}{ Cheese } & $\begin{array}{l}\text { Fat and sodium } \\
\text { content }\end{array}$ & $\begin{array}{l}\text { Curd washing, moderate } \\
\text { clotting, scalding, } \\
\text { temperature, ripening, and } \\
\text { high pasteurization }\end{array}$ & - & - & $\begin{array}{l}\text { Texture (hardness, } \\
\text { cohesiveness, adhesiveness, } \\
\text { and gumminess) }\end{array}$ & $\begin{array}{l}\text { Process + } \\
\text { properties }\end{array}$ & $\begin{array}{l}\text { Moatsou et al. } \\
\text { (2019) }\end{array}$ \\
\hline & $\begin{array}{l}\text { Microparticulated } \\
\text { whey protein }\end{array}$ & - & - & - & $\begin{array}{l}\text { Rheology (storage modulus, } \\
\mathrm{G}^{\prime} \text { ), texture (firmness, } \\
\text { adhesiveness and } \\
\text { cohesiveness), and Sensory } \\
\text { evaluation }\end{array}$ & $\begin{array}{l}\text { Product }+ \\
\text { properties }\end{array}$ & $\begin{array}{l}\text { Stankey et al. } \\
(2017)\end{array}$ \\
\hline \multirow[t]{2}{*}{$\begin{array}{l}\text { Ice } \\
\text { cream }\end{array}$} & - & $\begin{array}{l}\text { High-pressure } \\
\text { homogenization and melting }\end{array}$ & - & $\begin{array}{l}\text { Scanning } \\
\text { electron } \\
\text { microscopy }\end{array}$ & $\begin{array}{l}\text { Texture (hardness, } \\
\text { adhesiveness, gumminess, and } \\
\text { cohesiveness) }\end{array}$ & $\begin{array}{l}\text { Process + } \\
\text { properties }\end{array}$ & Sert et al. (2021) \\
\hline & - & Fermentation & - & $\begin{array}{l}\text { Scanning } \\
\text { electron } \\
\text { microscopy }\end{array}$ & $\begin{array}{l}\text { Rheology (apparent viscosity, } \\
\text { consistency coefficient, and } \\
\text { flow behavior index) }\end{array}$ & $\begin{array}{l}\text { Process + } \\
\text { properties }\end{array}$ & Dertli et al. (2016) \\
\hline \multirow[t]{2}{*}{ Butter } & - & Ripening and churning & - & - & $\begin{array}{l}\text { Rheology (elastic modulus and } \\
\text { viscous modulus) }\end{array}$ & $\begin{array}{l}\text { Process }+ \\
\text { properties }\end{array}$ & $\begin{array}{l}\text { Mtibaa et al. } \\
(2021)\end{array}$ \\
\hline & - & $\begin{array}{l}\text { High-pressure } \\
\text { homogenization }\end{array}$ & - & - & $\begin{array}{l}\text { Texture (firmness, consistency, } \\
\text { cohesiveness, and viscosity } \\
\text { index), spreadability, and } \\
\text { particle size }\end{array}$ & $\begin{array}{l}\text { Process + } \\
\text { properties }\end{array}$ & $\begin{array}{l}\text { Sert and Mercan } \\
(2020)\end{array}$ \\
\hline
\end{tabular}

treatments for analyzing the stability of casein micelles and milk fat (Cano-Sarmiento et al., 2018).

\subsection{Dairy Products on a Microscopic Scale}

Microstructural characterization is critical for understanding food properties and functionality (Auty 2011). Knowledge of food's microstructure is important for designing and controlling food processing operations and improving the quality of the final product (Joardder et al., 2015). Microscopic properties in food are characteristics, such as air pores, microcapillaries, cells, and fibers that can be found on a length scale of $0.1-100 \mathrm{~mm}$, forming a continuous body that requires light microscopy to be visualized (Auty 2011).

The microstructure is determined by complex molecular interactions and depends mainly on the organization of molecular compounds in the food matrix (Verboven et al., 2018). In dairy products, the microstructure is based on the spatial distribution of caseins, fat globules, water droplets, and air spaces (Fox et al., 2016). Protein and fat are the prominent influencers of the microscopic properties of food (Auty 2011; Truong et al., 2016; El-Bakry et al., 2018). However, in dairy products such as ice cream, the microscopic properties depend on the fat and protein content and the whey phase, ice crystals, and air (Goff and Hartel 2013). Electron microscopy is one way to understand the structure of foods. In the case of dairy products, electron microscopy makes it possible to observe casein micelles and their interactions with other components (Ong et al., 2013; El-Bakry et al., 2018).
Caseins are approximately $130-160 \mathrm{~nm}$ and can form microstructures in a wide density range depending on manufacturing conditions like heat treatment (DiazBustamante et al., 2020; Lucey et al., 2021; Spyropoulos et al., 2019). For instance, acid-induced dairy gels from heated milk are less porous than unheated milk and exhibit a homogeneous and rigid microstructure (Guinee 2016; Spyropoulos et al., 2019). Moreover, high processing temperatures produce a less dense crystal network and a protein/water distribution change in butter (Buldo and Wiking 2012).

The fat structure also plays a crucial role in the microstructure (Amador et al., 2017). It is related directly to sensory properties like mouthfeel, creaminess, flavor, and product stability (Crilly et al., 2008). Fat globules have a size of around $0.1-15 \mu \mathrm{m}$ (Lamichhane et al., 2018; Wiking et al., 2021) and can be seen in different morphologies in the microstructure of dairy products; for example, in the form of round droplets in the milk, like crystals in ice cream, or as a kind of amorphous phase in cheese (El-Bakry et al., 2018). Studies have shown that fat globule (FG) affects the physicochemical composition and macroscopic properties such as firmness and hardness (Logan et al., 2017; El-Bakry et al., 2018; Panchal et al., 2021). For instance, Logan et al. (2017) indicated that the FG size increased the moisture content in Cheddar cheese affecting its hardness.

In high-protein products, such as cheese, fat globules are usually trapped in the protein network, preventing their movement, and providing a firm texture to the product. However, during the ripening process, proteolytic enzymes 
alter the protein network, allowing the fat globules to escape, producing the characteristic oily appearance of aged cheese (Bhopatkar et al., 2012).

In recent studies, dairy products have been analyzed both by the association between fat and proteins (Macdougall et al., 2019) through different micrographic analysis techniques such as light microscopy, confocal scanning laser microscopy, scanning electron microscopy, and transmission electron microscopy (El-Bakry et al., 2018). However, few studies determine the microscopic properties through a global analysis of the influence of physicochemical composition, process conditions, and how the behavior and functionality of the molecular components are reflected in the microstructure of the dairy product.

\subsection{Dairy Products on a Macroscopic Scale}

Macroscopic properties can be defined as the spatial distribution of microscopic and molecular properties (Foegeding 2015). Such properties are associated with tangible and visible properties of the food, which can be measured by the naked eye (Ho et al., 2013).

Rheology and texture are macroscopic properties that describe the association of physical properties with mouthfeel and sensorial perception of food (Nguyen et al., 2018). Rheology is the science of deformation and flow, aimed at linking a material's flow properties with its structure and behavior during processing (Truong et al., 2016); These properties are measured through flow sweep, flow ramp, and oscillatory measurements. Textures are all mechanical, geometric, and surface attributes of a product perceived mechanically and tactilely (Pascua et al., 2013). The sensory attributes describe by textural analysis in foods are hardness, springiness, cohesiveness, adhesiveness, gumminess, and chewiness.

Rheological parameters and texture, as well as microscopic properties, depends on the interaction between proteins (Heertje 2014), pH (Ozcan et al., 2015), state of calcium (ionic or bound to the casein matrix) (Soodam et al., 2015), sodium chloride content (Diaz-Bustamante et al., 2020) and temperature (Asaduzzaman et al., 2021). However, these components can govern the different macroscopic properties of dairy products. For instance, Ong et al. (2020) studied the effect of $\mathrm{pH}$ variation on cream cheese production. These authors indicated that the microstructure was dense and cheese texture firmer as the $\mathrm{pH}$ decreased. In addition, other components also can govern the different macroscopic properties of dairy products. The rheological properties of ice cream are governed by ice crystals (Freire et al., 2020), whereas in butter, these properties are controlled by the crystalline structure of the fat (Buldo and Wiking 2012; Rønholt et al., 2013).

Some studies show that molecular components like fats and calcium content can affect dairy products' rheological properties and texture (Soodam et al., 2015). Macdougall et al. (2019) indicate that the hardness and gel strength generally correlated with high fat and high content increase the overall cohesiveness of Australian cream cheese.

Concerning process variables, heat treatment also affects these macroscopic properties (Buldo and Wiking 2012; Zhao et al.,
2016; Diaz-Bustamante et al., 2020). Denaturation of milk proteins by heating and interaction among denatured milk proteins dramatically affects the texture attributes, consistency, and storage moduli of dairy products (Zhao et al., 2016; Giroux et al., 2020; Lucey et al., 2021).

\section{LOOKING FORWARD}

The development of novel and functional dairy products has been of great interest to the dairy industry in recent years (Guiné and Lemos 2018). The demand for products with high nutritional value, with the incorporation of bioactive compounds, reduction or addition of fats, salts, and sugars with more significant contribution to health, has become a challenge for the design of these products because these ingredients or substitutes can modify the structure of dairy products (Meyer et al., 2011; Mudgil and Barak 2017; McCain et al., 2018). For example, inulin is a hydrocolloid that is considered a functional ingredient used as a fat substitute in dairy products (Li et al., 2019; Yousefi and Jafari 2019); however, Meyer et al. (2011)indicate that its incorporation is related to changes in the rheology of the foods. Yousefi and Jafari (2019) reviewed the functionality and application of various hydrocolloids in dairy products, including inulin. These authors noted that hydrocolloids affect dairy products' physical properties. These changes depend on the interaction with protein, $\mathrm{pH}$, temperature, ionic strength, chemical structure, and the concentration of hydrocolloids.

Many of the advances in the structural development of dairy products have focused on the application of new technologies such as ultra-pressure (Ravash et al., 2020), high-intensity ultrasound (Guimarães et al., 2019), microfluidization (Bucci et al., 2018), or pulsed electric fields to improve the texture of foods (Sfakianakis and Tzia 2014). The purpose of this is to improve the properties of the proteins with minimal changes in their organoleptic and nutritional characteristics (Ravash et al., 2020). For example, Siddique et al. (2016) indicate that pulsed light treatment improves whey protein's solubility and foaming ability. However, Nunes and Tavares (2019) highlight that these emerging technologies can modify the milk proteins' structure and techno-functional properties.

Other studies have pointed out the importance of microstructure, rheology, and textural attributes of dairy products, including manufacturing conditions and changes at molecular scale during the development of the food (Dertli et al., 2016; Huc et al., 2016); however, the analysis of all these elements as a whole remains limited. For instance, Pachekrepapol et al. (2021) developed a yogurt formulation from coconut milk. In this study, the authors evaluated the $\mathrm{pH}$ changes during storage (molecular scale) and the product's rheological and sensory properties (macroscopic scale), considering syneresis, color, and heating process. However, the authors have forgotten the effects caused by the incorporation of coconut milk on the microstructural properties of yogurt. Unlike the multiscale approach, similar studies have developed new dairy products through strategies that do not include the relationship between product-process-properties. A summary of these studies is shown in Table 1. 
A better understanding of their properties can address the design of dairy products at different scales, as well as the interconnection between them (i.e., a multiscale approach), which could lead to the estimation of structural properties, optimize the process, and develop new foods (Ho et al., 2013). The multiscale approach allows understanding the relationship between composition and formulation, the manufacturing process, and the properties of food through properties at the molecular, microscopic, and macroscopic scales, allowing the development of foods with specific desired properties.

Dairy products design at the molecular scale allows knowing all the interactions that occur in molecular compounds once they are subjected to process conditions and how these are associated with the formation of the product's structure. Then, dairy products design at the microscopic scale shows the spatial distribution of the molecular components and how this consequently affects the structure of the food. Finally, dairy products design at the macroscopic scale predicts the final characteristics through rheological and textural responses associated with tangible and visible properties of the food.

\section{REFERENCES}

Aguilera, J. M. (2006). Seligman Lecture 2005 Food Product Engineering: Building the Right Structures. J. Sci. Food Agric. 86 (8), 1147-1155. doi:10.1002/jsfa.2468 Amador, J., Hartel, R., and Rankin, S. (2017). The Effects of Fat Structures and Ice Cream Mix Viscosity on Physical and Sensory Properties of Ice Cream. J. Food Sci. 82 (8), 1851-1860. doi:10.1111/1750-3841.13780

Anema, S. G. (2020). "The Whey Proteins in Milk: Thermal Denaturation, Physical Interactions, and Effects on the Functional Properties of Milk," in Milk Proteins: From Expression to Food. 3rd ed. (Elsevier), 325-384. doi:10.1016/B978-0-12815251-5.00009-8

Aryee, A. N. A., Agyei, D., and Udenigwe, C. C. (2018). "Impact of Processing on the Chemistry and Functionality of Food Proteins," in Proteins in Food Processing (Elsevier Ltd.), 27-45. doi:10.1016/B978-0-08-100722-8.00003-6

Asaduzzaman, M., Mahomud, M. S., and Haque, M. E. (20212021). Heat-Induced Interaction of Milk Proteins: Impact on Yoghurt Structure. Int. J. Food Sci. 2021, 1-10. doi:10.1155/2021/5569917

Auty, M. (2011). "Analytical Methods | Microscopy (Microstructure of Milk Constituents and Products)," in Encyclopedia of Dairy Sciences. Second Edition, 226-234. doi:10.1016/B978-0-12-374407-4.00023-6

Barroso da Silva, F. L., Carloni, P., Cheung, D., Cottone, G., Donnini, S., Foegeding, E. A., et al. (2020). Understanding and Controlling Food Protein Structure and Function in Foods: Perspectives from Experiments and Computer Simulations. Annu. Rev. Food Sci. Technol. 11, 365-387. doi:10.1146/annurev-food-032519-051640

Bhopatkar, D., Hamaker, B. R., and Campanella, O. H. (2012). Micro to Macro Level Structures of Food Materials. Food Materials Science and Engineering. Wiley Online Library, 26-51. doi:10.1002/9781118373903.ch2

Bucci, A. J., Van Hekken, D. L., Tunick, M. H., Renye, J. A., and Tomasula, P. M. (2018). The Effects of Microfluidization on the Physical, Microbial, Chemical, and Coagulation Properties of Milk. J. Dairy Sci. 101 (8), 6990-7001. doi:10. 3168/jds.2017-13907

Buldo, P., and Wiking, L. (2012). The Role of Mixing Temperature on Microstructure and Rheological Properties of Butter Blends. J. Am. Oil Chem. Soc. 89 (5), 787-795. doi:10.1007/s11746-011-1965-y

Cano-Sarmiento, C., Téllez-Medina, D. I., Viveros-Contreras, R., Cornejo-Mazón, M., Figueroa-Hernández, C. Y., García-Armenta, E., et al. (2018). Zeta Potential of Food Matrices. Food Eng. Rev. 10 (3), 113-138. doi:10.1007/s12393-018-9176-z

Crilly, J. F., Russell, A. B., Cox, A. R., and Cebula, D. J. (2008). Designing Multiscale Structures for Desired Properties of Ice Cream. Ind. Eng. Chem. Res. 47, 6362-6367. doi:10.1021/ie701773z
For many years, dairy products have been the delivery vehicle for functional nutrients to the human body. Therefore, the food industry has been challenged to meet the demand for minimally processed products with as few additives as possible and healthier. Designing a food product is difficult even when the objective is to control the microstructure through textural and rheological analysis or processing conditions. However, it is possible to achieve significant results if specific molecular properties critical to an excellent product structure are considered. Therefore, the multiscale approach can lead to novel and functional dairy products by correlating a product's composition, process, and properties.

\section{AUTHOR CONTRIBUTIONS}

Conceptualization, MD-B, LR, and OA-S.; writing_original draft preparation, MD-B, MF-N, LR and OA-S.; writing-review and editing, MD-B, MF-N, LR and OA-S; funding acquisition, LR and OA-S. All authors have read and agreed to the published version of the manuscript.

Dertli, E., Toker, O. S., Durak, M. Z., Yilmaz, M. T., Tatlısu, N. B., Sagdic, O., et al (2016). Development of a Fermented Ice-Cream as Influenced by In Situ Exopolysaccharide Production: Rheological, Molecular, Microstructural and Sensory Characterization. Carbohydr. Polym. 136, 427-440. doi:10.1016/j. carbpol.2015.08.047

Diaz-Bustamante, M. L., Reyes, L. H., and Solano, O. A. A. (2020). Application of a Multiscale Approach in the Substitution and Reduction of $\mathrm{NaCl}$ in Costeño type Artisan Cheese. Appl. Sci. 10 (24), 9008-9011. doi:10.3390/app10249008

Dickinson, E. (2014). "Understanding Food Structures," in Food Structures, Digestion and Health (Elsevier), 3-49. doi:10.1016/B978-0-12-404610-8. 00001-3

El-Bakry, M., Sanchez, A., and Mehta, B. M. (2018). Microstructure of Dairy Products. John Wiley \& Sons. doi:10.1002/9781118964194

El-Bakry, M., and Sheehan, J. (2014). Analysing Cheese Microstructure: A Review of Recent Developments. J. Food Eng. 125, 84-96. doi:10.1016/j.jfoodeng.2013. 10.030

Fazilah, N. F., Ariff, A. B., Khayat, M. E., Rios-solis, L., and Halim, M. (2018). Influence of Probiotics, Prebiotics, Synbiotics and Bioactive Phytochemicals on the Formulation of Functional Yogurt. J. Funct. Foods 48, 387-399. doi:10.1016/ j.jff.2018.07.039

Foegeding, E. A. (2015). Food Protein Functionality-A New Model. J. Food Sci. 80 (12), C2670-C2677. doi:10.1111/1750-3841.13116

Fox, P. F., Guinee, T. P., Cogan, T. M., and McSweeney, P. L. H. (2016). "Cheese: Structure, Rheology and Texture," in Fundamentals of Cheese Science, 475-532. doi:10.1007/978-1-4899-7681-9_14

Freire, D. O., Wu, B., and Hartel, R. W. (2020). Effects of Structural Attributes on the Rheological Properties of Ice Cream and Melted Ice Cream. J. Food Sci. 85 (11), 3885-3898. doi:10.1111/1750-3841.15486

Giha, V., Ordoñez, M. J., and Villamil, R. A. (2021). How Does Milk Fat Replacement Influence Cheese Analogue Microstructure, Rheology, and Texture Profile? J. Food Sci. 86 (7), 2802-2815. doi:10.1111/1750-3841. 15799

Giroux, H. J., Dupont, F., Villeneuve, G., and Britten, M. (2020). Effect of Heating Milk on Whey Protein Denaturation and Cheese-Making Properties. Int. Dairy J. 111, 104831. doi:10.1016/j.idairyj.2020.104831

Goff, H. D., and Hartel, R. W. (2013). Ice Cream Structure. Ice Cream. Boston, MA: Springer, 313-352. doi:10.1007/978-1-4614-6096-1_11

Guimarães, J. T., Balthazar, C. F., Scudino, H., Pimentel, T. C., Esmerino, E. A., Ashokkumar, M., et al. (2019). High-intensity Ultrasound: A Novel Technology for the Development of Probiotic and Prebiotic Dairy Products. Ultrason. Sonochem. 57, 12-21. doi:10.1016/j.ultsonch.2019.05.004 
Guiné, R. P. F., and Lemos, E. T. D. (2018). Development of New Dairy Products with Functional Ingredients. J. Culinary Sci. Tech. 18 (3), 159-176. doi:10.1080/ 15428052.2018.1552901

Guinee, T. P. (2016). "Protein in Cheese and Cheese Products: Structure-Function Relationships," in Advanced Dairy Chemistry: Volume 1B: Proteins: Applied Aspects. Fourth Edition, 347-415. doi:10.1007/978-1-4939-2800-2_14

Heertje, I. (2014). Structure and Function of Food Products: A Review. Food Struct. 1 (1), 3-23. doi:10.1016/j.foostr.2013.06.001

Ho, Q. T., Carmeliet, J., Datta, A. K., Defraeye, T., Delele, M. A., Herremans, E., et al. (2013). Multiscale Modeling in Food Engineering. J. Food Eng. 114 (3), 279-291. doi:10.1016/j.jfoodeng.2012.08.019

Huc, D., Michon, C., Bedoussac, C., and Bosc, V. (2016). Design of a Multi-Scale Texture Study of Yoghurts Using Rheology, and Tribology Mimicking the Eating Process and Microstructure Characterisation. Int. Dairy J. 61, 126-134. doi:10.1016/j.idairyj.2016.05.003

Joardder, M. U. H., Kumar, C., and Karim, M. A. (2015). Food Structure: Its Formation and Relationships with Other Properties. Crit. Rev. Food Sci. Nutr. 57 (6), 1190-1205. doi:10.1080/10408398.2014.971354

Kaleda, A., Tsanev, R., Klesment, T., Vilu, R., and Laos, K. (2018). Ice Cream Structure Modification by Ice-Binding Proteins. Food Chem. 246, 164-171. doi:10.1016/j.foodchem.2017.10.152

Khan, I. T., Nadeem, M., Imran, M., Ullah, R., Ajmal, M., and Jaspal, M. H. (2019). Antioxidant Properties of Milk and Dairy Products: a Comprehensive Review of the Current Knowledge. Lipids Health Dis. 18 (1), 41-13. doi:10.1186/s12944019-0969-8

Lamichhane, P., Kelly, A. L., and Sheehan, J. J. (2018). Symposium Review: Structure-Function Relationships in Cheese. J. Dairy Sci. 101 (3), 2692-2709. doi:10.3168/jds.2017-13386

Li, H., Yu, H., Liu, Y., Wang, Y., Li, H., and Yu, J. (2019). The Use of of Inulin, Maltitol and Lecithin as Fat Replacers and Plasticizers in a Model Reduced-Fat Mozzarella Cheese-like Product. J. Sci. Food Agric. 99 (12), 5586-5593. doi:10. 1002/jsfa.9835

Logan, A., Xu, M., Day, L., Singh, T., Moore, S. C., Mazzonetto, M., et al. (2017). Milk Fat Globule Size Affects Cheddar Cheese Properties. Int. Dairy J. 70, 46-54. doi:10.1016/j.idairyj.2016.11.003

Loveday, S. M., Sarkar, A., and Singh, H. (2013). Innovative Yoghurts: Novel Processing Technologies for Improving Acid Milk Gel Texture. Trends Food Sci. Tech. 33 (1), 5-20. doi:10.1016/j.tifs.2013.06.007

Lucey, J. A., and Horne, D. S. (2018). Perspectives on Casein Interactions. Int. Dairy J. 85, 56-65. doi:10.1016/J.IDAIRYJ.2018.04.010

Lucey, J. A., Wilbanks, D. J., and Horne, D. S. (2022). Impact of Heat Treatment of Milk on Acid Gelation. Int. Dairy J. 125, 105222. doi:10.1016/j.idairyj.2021. 105222

Macdougall, P. E., Ong, L., Palmer, M. V., and Gras, S. L. (2019). The Microstructure and Textural Properties of Australian Cream Cheese with Differing Composition. Int. Dairy J. 99, 104548. doi:10.1016/j.idairyj.2019. 104548

McCain, H. R., Kaliappan, S., and Drake, M. A. (2018). Invited Review: Sugar Reduction in Dairy Products. J. Dairy Sci. 101 (10), 8619-8640. doi:10.3168/jds. 2017-14347

Meyer, D., Bayarri, S., Tárrega, A., and Costell, E. (2011). Inulin as Texture Modifier in Dairy Products. Food Hydrocolloids 25, 1881-1890. doi:10.1016/j. foodhyd.2011.04.012

Moatsou, G., Zoidou, E., Choundala, E., Koutsaris, K., Kopsia, O., Thergiaki, K., et al. (2019). Development of Reduced-Fat, Reduced-Sodium Semi-hard Sheep Milk Cheese. Foods 8, 204. doi:10.3390/foods8060204

Mousavi, M., Heshmati, A., Daraei Garmakhany, A., Vahidinia, A., and Taheri, M. (2019). Texture and Sensory Characterization of Functional Yogurt Supplemented with Flaxseed during Cold Storage. Food Sci. Nutr. 7 (3), 907-917. doi:10.1002/fsn3.805

Moussier, M., Huc-mathis, D., Michon, C., and Bosc, V. (2019). Rational Design of a Versatile Lab-Scale Stirred Milk Gel Using a Reverse Engineering Logic Based on Microstructure and Textural Properties. J. Food Eng. 249, 1-8. doi:10.1016/j. jfoodeng.2018.12.018

Mtibaa, I., Zouari, A., Attia, H., Ayadi, M. A., and Danthine, S. (2021). Effects of Physical Ripening Conditions and Churning Temperature on the ButterMaking Process and the Physical Characteristics of Camel Milk Butter. Food Bioproc. Technol 14 (8), 1518-1528. doi:10.1007/s11947-021-02649-4
Mudgil, D., Barak, S., and Khatkar, B. S. (2017). Texture Profile Analysis of Yogurt as Influenced by Partially Hydrolyzed Guar Gum and Process Variables. J. Food Sci. Technol. 54 (12), 3810-3817. doi:10.1007/s13197-017-2779-1

Nguyen, H. T. H., Afsar, S., and Day, L. (2018). Differences in the Microstructure and Rheological Properties of Low-Fat Yoghurts from Goat, Sheep and Cow Milk. Food Res. Int. 108, 423-429. doi:10.1016/j.foodres.2018.03.040

Nunes, L., and Tavares, G. M. (2019). Thermal Treatments and Emerging Technologies: Impacts on the Structure and Techno-Functional Properties of Milk Proteins. Trends Food Sci. Tech. 90 (June), 88-99. doi:10.1016/j.tifs. 2019.06.004

Ong, L., Dagastine, R. R., Kentish, S. E., and Gras, S. L. (2012). The Effect of $\mathrm{pH}$ at Renneting on the Microstructure, Composition and Texture of Cheddar Cheese. Food Res. Int. 48 (1), 119-130. doi:10.1016/j.foodres. 2012.02.020

Ong, L., Dagastine, R. R., Kentish, S. E., and Gras, S. L. (2013). The Effect of Calcium Chloride Addition on the Microstructure and Composition of Cheddar Cheese. Int. Dairy J. 33 (2), 135-141. doi:10.1016/j.idairyj.2013.03.002

Ong, L., Pax, A. P., Ong, A., Vongsvivut, J., Tobin, M. J., Kentish, S. E., et al. (2020). The Effect of $\mathrm{pH}$ on the Fat and Protein within Cream Cheese and Their Influence on Textural and Rheological Properties. Food Chem. 332, 127327. doi:10.1016/j.foodchem.2020.127327

Ozcan, T., Horne, D. S., and Lucey, J. A. (2015). Yogurt Made from Milk Heated at Different pH Values. J. Dairy Sci. 98 (10), 6749-6758. doi:10.3168/jds.20159643

Pachekrepapol, U., Kokhuenkhan, Y., and Ongsawat, J. (2021). Formulation of Yogurt-like Product from Coconut Milk and Evaluation of Physicochemical, Rheological, and Sensory Properties. Int. J. Gastronomy Food Sci. 25, 100393. doi:10.1016/j.ijgfs.2021.100393

Panchal, B., Truong, T., Prakash, S., Bansal, N., and Bhandari, B. (2021). Influence of Fat Globule Size, Emulsifiers, and Cream-Aging on Microstructure and Physical Properties of Butter. Int. Dairy J. 117, 105003. doi:10.1016/j.idairyj. 2021.105003

Pascua, Y., Koç, H., and Foegeding, E. A. (2013). Food Structure: Roles of Mechanical Properties and Oral Processing in Determining Sensory Texture of Soft Materials. Curr. Opin. Colloid Interf. Sci. 18 (4), 324-333. doi:10.1016/j. cocis.2013.03.009

Pereira, P. C. (2014). Milk Nutritional Composition and its Role in Human Health. Nutrition 30 (6), 619-627. doi:10.1016/j.nut.2013.10.011

Ravash, N., Peighambardoust, S. H., Soltanzadeh, M., Pateiro, M., and Lorenzo, J. M. (2020). Impact of High-Pressure Treatment on Casein Micelles, Whey Proteins, Fat Globules and Enzymes Activity in Dairy Products: a Review. In Critical Reviews in Food Science and Nutrition. Taylor \& Francis, 1-21. doi:10. 1080/10408398.2020.1860899

Rønholt, S., Mortensen, K., and Knudsen, J. C. (2013). The Effective Factors on the Structure of Butter and Other Milk Fat-Based Products. Compr. Rev. Food Sci. Food Saf. 12, 468-482. doi:10.1111/1541-4337.12022

Sert, D., Mercan, E., and Kılınç, M. (2021). Development of buffalo Milk Ice-Cream by High Pressure-Homogenisation of Mix: Physicochemical, Textural and Microstructural Characterisation. LWT 150, 112013. doi:10.1016/j.lwt.2021. 112013

Sert, D., and Mercan, E. (2020). Microbiological, Physicochemical, Textural Characteristics and Oxidative Stability of Butter Produced from HighPressure Homogenisation Treated Cream at Different Pressures. Int. Dairy J. 111, 104825. doi:10.1016/j.idairyj.2020.104825

Sfakianakis, P., and Tzia, C. (2014). Conventional and Innovative Processing of Milk for Yogurt Manufacture; Development of Texture and Flavor: A Review. Foods 3, 176-193. doi:10.3390/foods3010176

Siddique, M. A. B., Maresca, P., Pataro, G., and Ferrari, G. (2016). Effect of Pulsed Light Treatment on Structural and Functional Properties of Whey Protein Isolate. Food Res. Int. 87, 189-196. doi:10.1016/j.foodres.2016. 07.017

Smith, J. R., Carr, A. J., Golding, M., and Reid, D. (2017). Mozzarella Cheese - A Review of the Structural Development during Processing. Food Biophys. 13 (1), 1-10. doi:10.1007/s11483-017-9511-6

Soodam, K., Ong, L., Powell, I. B., Kentish, S. E., and Gras, S. L. (2015). Effect of Calcium Chloride Addition and Draining $\mathrm{pH}$ on the Microstructure and Texture of Full Fat Cheddar Cheese during Ripening. Food Chem. 181, 111-118. doi:10.1016/j.foodchem.2015.01.135 
Spyropoulos, F., Lazidis, A., and Norton, I. T. (2019). Handbook of Food Structure Development. The Royal Society of Chemistry. doi:10.1039/9781788016155FP001

Stankey, J. A., Lu, Y., Abdalla, A., Govindasamy-Lucey, S., Jaeggi, J. J., Ø Mikkelsen, B., et al. (2017). Low-fat Cheddar Cheese Made Using Microparticulated Whey Proteins: Effect on Yield and Cheese Quality. Int. J. Dairy Technol. 70, 481-491. doi:10.1111/1471-0307.12413

Truong, T., Palmer, M., Bansal, N., and Bhandari, B. (2016). "Effect of Milk Fat Globule Size on Functionalities and Sensory Qualities of Dairy Products," in Effect of Milk Fat Globule Size on the Physical Functionality of Dairy Products (Cham: Springer), 47-67. doi:10.1007/978-3-319-23877-7_7

Tunick, M. H., and Van Hekken, D. L. (2014). Dairy Products and Health: Recent Insights. J. Agric. Food Chem. 63, 9381-9388. doi:10.1021/jf5042454

Verboven, P., Defraeye, T., and Nicolai, B. (2018). "Measurement and Visualization of Food Microstructure," in Food Microstructure and its Relationship with Quality and Stability (Elsevier Ldt.), 3-28. doi:10.1016/B978-0-08-100764-8. 00001-0

Vianna, F. S., Canto, A. C. V. C. S., da Costa-Lima, B. R. C., Salim, A. P. A. A., Costa, M. P., Balthazar, C. F., et al. (2017). Development of New Probiotic Yoghurt with a Mixture of Cow and Sheep Milk: Effects on Physicochemical, Textural and Sensory Analysis. Small Ruminant Res. 149, 154-162. doi:10.1016/ j.smallrumres.2017.02.013

Wiking, L., Gregersen, S. B., Hansen, S. F., and Hammershøj, M. (2022). Heatinduced Changes in Milk Fat and Milk Fat Globules and its Derived Effects on Acid Dairy Gelation - A Review. Int. Dairy J. 127, 105213. doi:10.1016/j.idairyj. 2021.105213
Yousefi, M., and Jafari, S. M. (2019). Recent Advances in Application of Different Hydrocolloids in Dairy Products to Improve Their TechnoFunctional Properties. Trends Food Sci. Tech. 88, 468-483. doi:10.1016/j. tifs.2019.04.015

Zhao, L. L., Wang, X. L., Tian, Q., and Mao, X. Y. (2016). Effect of Casein to Whey Protein Ratios on the Protein Interactions and Coagulation Properties of Low-Fat Yogurt. J. Dairy Sci. 99 (10), 7768-7775. doi:10.3168/jds.201510794

Conflict of Interest: The authors declare that the research was conducted in the absence of any commercial or financial relationships that could be construed as a potential conflict of interest.

Publisher's Note: All claims expressed in this article are solely those of the authors and do not necessarily represent those of their affiliated organizations, or those of the publisher, the editors and the reviewers. Any product that may be evaluated in this article, or claim that may be made by its manufacturer, is not guaranteed or endorsed by the publisher.

Copyright (c) 2022 Díaz-Bustamante, Fernández-Niño, Reyes and Alvarez Solano. This is an open-access article distributed under the terms of the Creative Commons Attribution License (CC BY). The use, distribution or reproduction in other forums is permitted, provided the original author(s) and the copyright owner(s) are credited and that the original publication in this journal is cited, in accordance with accepted academic practice. No use, distribution or reproduction is permitted which does not comply with these terms. 